\title{
PENGARUH PENGUNAAN MEDIA PAPAN KARTU TEKA-TEKI UNTUK MEINGKATKAN PERKEMBANGAN KOGNITIF ANAK KELOMPOK B TK GENERASI HARAPAN KECAMATAN SUKODADI KABUPATEN LAMONGAN
}

\author{
Dina Fitriana a 1 \\ ${ }^{\text {a }}$ Universitas Islam Lamongan Indonesia \\ 1 dinafitrianasg@gmail.com
}

\begin{tabular}{l}
\hline Informasi artike \\
\hline Received : \\
Feb 15, 2019. \\
Revised : \\
Feb 27, 2019. \\
Publish : \\
Maret 09, 2019. \\
Kata kunci: \\
Perkembangan \\
Kognitif; \\
Papan Kartu; \\
Media Puzel
\end{tabular}

Keywords:

Cognitive

development

Card board;

Puzzle media;

\begin{abstract}
ABSTRAK
Permasalahan dalam penelitian ini adalah: (1) bagaimana perkembangan kognitif anak; (2) apakah ada kesulitan dalam menggunakan media puzzle papan kartu; (3) apakah ada pengaruh media papan kartu terhadap perkembangan kognitif anak. Tujuan dari penelitian ini adalah (1) untuk mengetahui tingkat perkembangan kognitif anak; (2) untuk mengetahui kesulitan menggunakan media puzzle papan kartu; (3) untuk mengetahui pengaruh media puzzle papan kartu. Subjek dalam penelitian ini adalah siswa di kelompok TK Generasi Harapan di Kecamatan Sukodadi yang terdaftar pada tahun ajaran 2018/2019. Ada 23 anak. Hasil penelitian pada kelompok B di TK Kabupaten Sukodadi menunjukkan bahwa dari 23 anak yang menjadi subjek penelitian tentang pengembangan kognitif dalam menggunakan media kartu papan puzzle untuk mengetahui namanama kendaraan darat. Desain penelitian ini menggunakan hasil eksperimen teknik pengumpulan data yang digunakan adalah observasi dan dokumentasi. Teknik analisis yang digunakan adalah statistik deskriptif dan statistik diferensial.
\end{abstract}

\section{ABSTRACT}

The problems in this study are: (1) how children's cognitive development; (2) is there any difficulty in using card board puzzle media; (3) whether there is influence of card board media on children's cognitive development. The purpose of this study is (1) to determine the level of cognitive development of children; (2) to find out the difficulty of using card board puzzle media; (3) to find out the influence of the card board puzzle media. The subjects in this study were students in the Generasi Harapan kindergarten group in Sukodadi Subdistrict which were registered in the 2018/2019 school year. There are 23 children. The results of the study in group B in TK Sukodadi District showed that of 23 children who were the subjects of research on cognitive development in using puzzle board card media to get to know the names of land vehicles. The design of this study uses the experimental results of data collection techniques used are observation and documentation. The analysis technique used is descriptive statistics and differential statistics.

This work is licensed under a Creative Commons Attribution-ShareAlike 4.0 International License. Allows readers to read, download, copy, distribute, print, search, or link to the full texts of its articles and allow readers to use them for any other lawful purpose. 


\section{PENDAHULUAN}

Pendidikan anak usia dini sangatlah penting untuk mengembangkan dan menstimulus potensi anak, dimana anak usia dini berada dalam tahap pertumbuhan dan perkembangan yang sangat pesat, baik fisik maupun mental (Slamet, 2005:5). Maka sangat tepat apabila anak usia dini disebut sebagai usia emas (golden age), dimana anak sangat berpotensi untuk mempelajari segala hal dengan cepat. Pada masa ini khususnya usia 4-6 tahun anak mengalami masa peka, anak sangat sensitif untuk menerima berbagai stimulus. Masa peka adalah masa terjadinya pematangan fungsifungsi fisik dan psikis yang siap merespon stimulasi yang diberikan oleh lingkungan sekitar anak.

Proses pembelajaran di Taman Kanak-kanak bertujuan memberikan konsepkonsep dasar yang memiliki kebermaknaan bagi anak melalui pengalaman nyata yang memungkinkan anak menunjukkan aktivitas dan rasa ingin tahu.

Hadirnya media dalam proses pembelajaran sangat membantu anak didik lebih memahami hal yang dipelajari. Oleh sebab itu, pemilihan dan penggunaan media harus benar-benar tepat agar tujuan yang diinginkan dapat tercapai dengan mudah. Pada akhirnya, pemanfaatan dan penggunaan media menunjang efektivitas, efisiensi, dan daya tarik dalam pembelajaran (Setyosari, 2008:7)

Media tidak hanya memberikan pengalaman nyata tetapi juga membantu anak mengintegrasikan pengalaman-pengalaman anak sebelumnya. Dengan demikian diharapkan media akan dapat memperlancar proses belajar anak serta pemahaman terhadap materi pembelajaran. Disamping itu media dapat menarik perhatian serta mampu membangkitkan minat dan meningkatkan motivasi belajar anak. Motivasi 
merupakan seni yang mampu mendorong anak melakukan kegiatan belajar sehingga tujuan belajar dapat tercapai (Munadi, 2008:47).

Ketika anak bermain, anak akan mempelajari dan menyerap segala sesuatu yang terjadi di lingkungan sekitarnya. Selain itu, lingkungan atau alam sekitar yang mengundang anak untuk menyenangi pembelajarannya. pengalaman belajar tampak ketika anak memiliki kesempatan untuk beraktivitas fisik yang menggerakkan anak untuk bermain dengan senang hati, bebas mengatur, dan mempelajari sesuatu dengan mudah. Belajar akan terjadi jika anak terlibat aktif dan dapat mengambil bagian dari setiap tahap permainan. Anak akan belajar melalui pengalaman seutuhnya, mencermati detail bentuk, warna, ukuran, dan dapat membandingkannya dengan benda sejenis.

Dalam penelitian ini penggunaan media papan kartu teka-teki diharapkan dapat membantu dan memudahkan anak dalam mengenal jenis dan nama kendaraan. Dengan cara mengetahui ciri-ciri kendaraan yaitu bagaimana kendaraan dapat bergerak, roda yang terdapat dalam kendaraan dan jumlah penumpang yang naik pada kendaraan.

Berdasarkan observasi awal di TK Generasi Harapan kecamatan Sukodadi Lamongan pada 23 orang anak TK kelompok B, sebagian perkembangan kognitif anak masih kurang yaitu dalam pembelajaran dengan tema kendaraan. Pada saat pembelajaran, sebagian anak belum mengetahui ciri-ciri kendaraan dan kemampuan menghitung benda juga masih kurang. Dalam kegiatan belajar mengajar, guru masih sebagai pusat dalam pembelajaran. Anak menjadi pendengar saja sehingga pembelajaran terasa jenuh dan bosan, anak kebanyakan bercakap-cakap dengan temannya serta tidak memperhatikan penjelasan guru. 
Pada kegiatan pembelajaran harus terjadi proses komunikasi dua arah, artinya antara pemberi pesan dengan penerima pesan harus saling aktif, oleh karena itu peran media pembelajaran sangat penting dalam menyampaikan pesan khususnya untuk anak di Taman Kanak-kanak sehingga media pembelajaran yang digunakan harus menarik minat belajar anak.

Salah satu solusi pemecahan dalam proses pembelajaran adalah dengan penggunaan media yang inovatif dan kreatif dalam pembelajaran. Media yang digunakan hendaknya dapat merangsang anak untuk lebih semangat dalam kegiatan belajar. Media pembelajaran banyak macamnya, salah satunya adalah media papan kartu teka teki yang merupakan contoh media dengan menggunakan kartu bergambar yang membantu anak dalam pembelajaran untuk meningkatkan perkembangan kognitif anak. Melalui media papan kartu teka-teki anak TK di Kelompok B yang dapat meningkatkan perkembangan kognitif anak, media papan kartu bertujuan untuk memberi pengetahuan pada anak dengan diberi teka-teki pertanyaan seputar kendaraan yang dibacakan oleh guru yaitu jenis dan nama kendaraan yang sering dijumpai disekitar lingkungan tempat tinggal (sepeda, motor, becak, delman, mobil, bus, kereta api, dll), ciri-ciri kendaraan yaitu (memiliki roda berapa?, bergerak dengan cara bagaimana?, disebut siapa pengendaranya?), kemudian anak menebak teka-teki dengan mencari gambar kendaraan yang telah ditebak pada media papan yang berisi jenis-jenis kendaraan dan anak mulai mencocokkannya dengan memberi tanda serta menghitung banyaknya kendaraan yang telah ditebak,

Dengan demikian, diharapkan media papan kartu teka-teki dapat membantu dalam meningkatkan perkembangan kognitif anak kelompok B di TK Generasi Harapan Kecamatan Sukodadi Kabupaten Lamongan. 


\section{METODOLOGI}

Desain penelitian merupakan sebuah rancangan penelitian yang akan dilaksanakan. Pada penelitian ini digunakan jenis penelitian quasi eksperimen dengan desain yang digunakan adalah posttest control group desain. Sampel yang diambil dalam penelitian dibagi atas dua kelas yaitu kelas eksperiemen dan kelas kontrol. Untuk kelas eksperimen diberikan media papan kartu teka-teki, sedangkan untuk kelas kontrol menggunakan lembar kerja siswa di TK Generasi Harapan Kecamatan Sukodadi Kecamatan Lamongan dari populasi seluruh anak kelompok B yaitu 23 anak.

Variabel yang di gunakan dalam penelitian ini objek penelitian adalah apa yang menjadi titik perhatian suatu penelitian. Sesuai dengan permasalahan yang telah dirumuskan maka variabel penelitian ini terdiri atas 2 yaitu:

a. Variabel bebas (independent variabel) adalah variabel yang mempengaruhi terhadap suatu gejalah yang disebut dengan variabel $\mathrm{X}$. dalam penelitian ini yang menjadi variabel bebas $(\mathrm{X})$ adalah media Papan kartu teka-teki

b. Variabel terikat (dependent variabel) adalah variabel yang di pengaruh dengan variabel (Y) atau perkembangan kognitif anak.

Kegiatan dalam analisis data adalah mengelompokkan data berdasarkan variabel dari seluruh responden, menyajikan data setiap variabel yang diteliti, melakukan perhitungan untuk menguji hipotesis dengan teknik analisis data yang digunakan pada penelitian ini adalah statistik inferensial. Inferensial adaalaah teknik statistik yang digunakan untuk menganalisis data sampel dan hasilnya diberlakukan untuk poplasi. 
Teknik pengambilan sampel yang digunakan dalam penelitian ini adalah Purposive Sampling karena untuk menentukan seseorang menjadi sampel dengan pertimbangan kepentingan subyek yang akan diteliti dalam usaha memperoleh informasi yang relevan dengan tujuan penelitian (Arifin, 2008:80).

Uji normalitas digunakan untuk mengetahui data dari masing-masing kelompok (eksperimen dan kontrol) berasal dari populasi yang berdistribusi normal atau tidak. Hal ini sangat penting dilakukan untuk dapat menentukan teknik analisis yang tepat untuk kondisi awal yang ada, yakni menggunakan statistik parametrik ataupun non-parametrik. Untuk keperluan tersebut digunakan uji KolmogorovSmirnov $(K-S)$, dengan menggunakan bantuan komputer program SPSS 22 for Windows. Dalam hal ini, hipotesis yang diuji adalah:

$H_{0}=$ Sampel berasal dari populasi pendistribusian normal.

$H_{1}=$ Sampel tidak berasal dari populasi pendistribusian normal.

Dasar pengambilan keputusan untuk mengetahui apakah varians populasi adalah normal atau tidak adalah:

1) Jika nilai signifikasi probabilitasnya ( $p$ ) lebih besar dari nilai signifikasi $\alpha=0,05$, maka distribusi data normal.

2) Jika nilai signifikasi probabilitasnya ( $p$ ) lebih kecil dari nilai signifikasi $\alpha=0,05$, maka distribusi data tidak normal.

Uji homogenitas digunakan untuk menguji kesamaan varians antara dua kelompok perlakuan. Pengujian homogenitas dengan menggunakan uji Levence dengan bantuan SPSS 22 for windows. Kriteria pengujian digunakan pada taraf sifnifikasi 0,05 (Sugiyono, 2011:203).

Dalam hal ini hipotesis yang diuji adalah: 
$H_{0}=$ Varians dalam tiap kelompok sama (homogen).

$H_{1}=$ Varians dalam tiap kelompok tidak sama (tidak homogen).

Dasar pengambilan keputusan untuk mengetahui apakah varians populasi adalah homogen atau tidak, yaitu:

1) Jika nilai signifikasi hasil perhitungan ( $p$ ) lebih besar dari nilai signifikasi $\alpha=0,05$, maka dinyatakan homogen.

2) Jika nilai signifikasi hasil perhitungan ( $p$ ) lebih kecil dari nilai signifikasi $\alpha=0,05$, maka dinyatakan tidak homogen.

Untuk melihat bagaimanakah pengaruh variabel bebas terhadap variabel terikatnya. Uji tersebut dikenal juga dengan sebutan uji F.

a. Jika $\mathrm{F}_{\text {hitung }}>\mathrm{F}_{\text {tabel }}$ maka $\mathrm{H}_{\mathrm{o}}$ ditolak artinya signifikan

b. Jika $\mathrm{F}_{\text {hitung }}<\mathrm{F}_{\text {tabel }}$ maka $\mathrm{H}_{\mathrm{o}}$ diterima artinya tidak signifikan

Uji hipotesis dalam penelitian ini menggunakan hipotesis statistik, untuk menganalisis data menggunakan bantuan komputer program SPSS 22 for Windows.

Ada dua jenis hipotesis yang digunakan dalam penelitian, yaitu:

1. Hipotesis kerja atau hipotesis alternatif (Ha). Hipotesis kerja menyatakan adanya hubungan antara variabel X dan variabel Y, adanya perbedaan antara dua kelompok.

2. Hipotesis nol atau null hypotheses (Ho). Hipotesis nol sering disebut hipotesis statistik, karena biasanya sering dipakai dalam penelitian yang bersifat statistik. Hipotesis nol menyatakan tidak adanya hubungan atau tidak ada pengaruh antara dua variabel, yaitu variabel $\mathrm{X}$ terhadap variabel $\mathrm{Y}$.

Pengambilan keputusan berdasarkan perbandingan dengan $\mathrm{F}_{\text {hitung }}$ dengan $\mathrm{F}_{\text {tabel }}$, sebagai berikut:

Jika taraf signifikan $<0,05$, maka Ha diterima dan Ho ditolak. 
Jika taraf signifikan $>0,05$, maka Ha ditolak dan Ho diterima.

\section{HASIL PENELITIAN}

Penelitian ini berjudul "Pengaruh penggunaan media papan kartu teka-teki dapat membantu dalam meningkatkan perkembangan kognitif anak kelompok B di TK Generasi Harapan Kecamatan Sukodadi Kabupaten Lamongan.” menggunakan pendekatan kuantitatif. Jenis penelitian yang digunakan penelitian eksperimen yaitu untuk mengetahui ada tidaknya pengaruh dari sesuatu yang dikenalkan pada sampel penelitian. Penelitian eksperimen yang dilaksanakan menggunakan kelompok pembanding. Penelitian ini memberikan perlakuan yang diberikan pada suatu kelompok.

Dalam pengujian hipotesis penelitian dilakukan dengan menggunakan statistik diferensial. Maka sebelum dilakukan pengujian hipotesis terlebih dahulu dilakukan uji peryaratan dengan langkah-langkah sebagai berikut:

\section{a. Uji Normalitas}

Uji normalitas data untuk mengetahui keadaan yang diteliti uji normalitas data yaitu dengan uji liliefors sebagai berikut:

Berdasarkan data penelitian diperoleh nilai Lhitung untuk kelas eksperimen sebesar 0,116 kemudian nilai ini dibandingkan dengan nilai Ltabel pada taraf $\alpha=5 \%$ $(0,05)$ dengan nilai Ltabel sebesar 0,167. Karena nilai Lhitung < Ltabel yaitu 0,116 < 0,167 maka dapat disimpulkan bahwa data-data perkembangan kognitif yang diajarkan dengan media papan kartu teka-teki berdistribusi normal.

Berdasarkan hasil perhitungan diatas diperoleh nilai Lhitung untuk kelas kontrol sebesar 0, 0,126 kemudian nilai ini dibandingkan dengan nilai Ltabel pada 
taraf signifikan $\alpha=5 \%(0,05)$ dengan nilai Ltabe sebesar 0,167 . Karena nilai Lhitung $<$ Ltabel yaitu 0, $0126<0,167$ maka dapat disimpulkan bahwa data-data perkembangan kognitif yang diajarkan dengan lembar kerja siswa berdistribusi normal.

\section{b. Uji Homogen}

Uji Homogen untuk membandingkan terhadap data hasil belajar terhadap perkembangan kognitif pada anak dari kesamaan kedua kelas apakah ada kesamaan varians (homogen).

Berdasarkan data post-test pada taraf signifikan $\alpha=5 \%(0,05)$ diperoleh Fhitung $=1,0$ Ftabel $=1,95$ karena Fhitung $<$ Ftabel atau 1,0 sehingga dapat disimpulkan bahwa data dari kedua sampel untuk post-test mempunyai varians yang sama atau homogen.

\section{c. Uji Hipotesis}

Hasil penelitian ini menemukan bahwa perkembangan kognitif anak pada kelas eksperimen lebih tinggi dari pada anak pada kelas kontrol. Hal ini disebabkan karena pada kelas eksperimen anak mendapatkan treatment atau perlakuan berupa penggunaan media papan kartu teka-teki. Sedangkan pada kelas kontrol tidak mendapat treatment atau perlakuan dan dengan menggunakan lembar kerja siswa dalam pembelajaran yang dilakukan di dalam kelas.

Uji hipotesis dilakukan dengan menggunakan uji t pada tingkat kepercayaan $95 \%$ pada $\alpha=5 \%(0,05)$ dan $\mathrm{dk}(\mathrm{n} 1+\mathrm{n} 2)-2$ dengan kriteria pengujian yang berlaku adalah Ha diterima apabila thitung>ttabel dan H0 ditolak apabila thitung>ttabel sampel 23 masing-masing kelas eksperimen dan kelas kontrol adalah 11 dan 12 anak. 
Dari penelitian tersebut terlihat bahwa thitung sebesar 22,58 dan ttabel sebesar 2.00845 pada taraf signifikan $\alpha=5 \%(0,05)$ karena nilai thitung $>$ ttabel yaitu $(22,58>2.00845)$ maka dapat disimpulkan terdapat pengaruh positif dan signifikan penggunaan media papan kartu teka-teki terhadap perkembangan kognitif pada anak Di TK Generasi Harapan Kecamatan Sukodadi Kabupaten Lamongan.

\section{PENUTUP}

Penggunaan media papan kartu teka-teki berpengaruh secara signifikan terhadap perkembangan kognitif anak TK Generasi Harapan kelompok B di Kecamatan Sukodadi Kabupaten Lamongan.

Uji One Way Anova membuktikan bahwa $\mathrm{H}_{0}$ ditolak dan menerima $\mathrm{H}_{\mathrm{a} 1}$ yang diketahui dari nilai $F_{\text {hitung }}$ sebesar 2.00845 lebih besar dari $F_{\text {tabel }}$ sebesar 22,58. Terdapat perbedaan nilai rata-rata kelas perkembangan kognitif kelompok eksperimen yaitu 0,167 lebih besar daripada kelompok kontrol sebesar 0,0126.

Berdasarkan data post-test pada taraf signifikan $\alpha=5 \%(0,05)$ diperoleh Fhitung $=1,0$ Ftabel $=1,95$ karena Fhitung $<$ Ftabel atau 1,0 sehingga dapat disimpulkan bahwa data dari kedua sampel untuk post-test mempunyai varians yang sama atau homogen.

Sehingga dalam penelitian penggunaan media papan kartu teka-teki dapat meningkatkan perkembangan kognitif anak. 


\section{REFERENSI}

Arifin, Zaenal. Metodologi PenelitianPendidikan Filosofi, Teori, dan Aplikasi. Jakarta: Lentera Cendikia, 2008

Arikunto. Prosedur Penelitian Suatu Pendekatan Praktik. (Jakarta: Rhineka Cipta, 2006

Arikunto, Suharsimi. Prosedur penelitian suatu pendekatan praktek. Jakarta: PT Bina Aksara, 2006

Munadi, Yudhi . Media Pembelajaran: sebuah pendekatan baru. Jakarta: GP. Press, 2008

Setyosari, Punaji. Pemilihan dan Penggunaan Media Pembelajaran. Malang: Panitia Sertifikasi Guru Rayon 15 Universitas Negeri Malang, 2008

Slamet, Suyanto. Dasar-Dasar Pendidikan Anak Usia Dini. Jakarta: Hikayat, 2005

Sugiyono. Metode Penelitian Kuantitatif Dan R \& D. Bandung: Alfabeta, 2011 